\title{
THE LIGHTS AND SHADOWS OF SISTERHOOD: REVISITING FAY WELDON'S FEMALE FRIENDS (1974) IN THE FOURTH WAVE
}

\author{
Teresa Martínez Quiles, University of Alicante \\ Email: teresa.martinezquiles@gmail.com
}

Received: July 31, 2020

Accepted: November 24, 2020

\begin{abstract}
In light of the current feminist fourth wave, when the notion of sisterhood seems to be recurrent in popular discourse, this paper aims to examine the literary representation of this concept through Fay Weldon's novel Female Friends (1974). I argue that, although Weldon does advance the possibility of sisterhood, she also questions some of the premises that were underlying this term during the second wave. Furthermore, my contention is that the novel addresses the importance of women's individual agency, a discourse especially strong in the third and fourth waves as a necessary step towards the construction of sisterhood.
\end{abstract}

Keywords: Sisterhood, female relations, second wave, fourth wave, feminism.

Resumen: Dado que una de las características de la cuarta ola feminista parece ser la presencia del concepto de sororidad en la cultura popular, este artículo pretende explorar la representación literaria del mismo a través de la obra Female Friends (1974), escrita por Fay Weldon. Por un lado, se intentará señalar como Weldon, a pesar de reivindicar la posibilidad de la sororidad, desmantela algunas de las premisas subyacentes a la visión de la segunda ola. Además, el artículo argumenta que la novela aborda la importancia de la agencia individual de la mujer, un discurso especialmente presente en la tercera y cuarta ola, como paso imprescindible para el desarrollo de la sororidad.

Palabras clave: Sororidad, relaciones femeninas, segunda ola, cuarta ola, feminismo.

\section{INTRODUCTION: SISTERHOOD IN THE FOURTH WAVE}

In the wake of the Me Too movement, Western society is said to be fully immersed in a new period of feminist activism, one that has already been recognized as the fourth wave by journalists like Kira Cochrane (2013) and scholars such as Prudence Chamberlain (2017) or Nicola Rivers (2017). According to Cochrane (2013), this new reality is characterized 
by online activism and is mainly focused on issues like gender violence or rape culture. It is supposed to have started around 2011, after a Canadian police officer told female high school students that, in order to prevent sexual harassment, they should avoid dressing provocatively, thereby putting the blame on the victim rather than the perpetrator (Chamberlain 2017: 111). Such incident sparked a series of marches and manifestations known as SlutWalks which had the intention of ending women's stigmatization in cases of sexual assault by ironically empowering women through the word slut, a term traditionally used to demean them (Palakurthi 2015: n.p.). Only a year later, two events occurred which would prepare the ground for this new wave (Chamberlain 2017). The first was the rape of a high school student in Steubenville, Ohio, who was later humiliated and stigmatized on social media through the spread of intimate photos of the assault. The second event was the launching of an online campaign called Everyday Sexism by Laura Bates, who wanted to encourage women to denounce the online daily sexist incidents they suffered. This initiative, which quickly went viral, is particularly important for the fourth wave because it marks a turning point in online activism. As Rivers maintains (2017: 24), Bates's project evokes in certain ways the social collectivism of the second wave, in that it encourages solidary acts between women. Years later, the same could also be said for the Me Too movement.

Following Alyssa Milano's viral tweet requesting her followers to confess if they had ever experienced any sort of sexual abuse with the hashtag \#metoo, a phrase which was coined in 2006 by civil rights activist Tarana Burke, thousands of women started coming forward with their stories on Twitter (Pflum 2018: n.p.). According to journalists like Mandakini Gahlot (Aravind 2018: n.p.) and Harriet Harman (2018: n.p.), the response to these confessions in the form of supportive messages like "I hear you" or "I believe you" helped forge a feeling of online sisterhood providing comfort and hope towards the eradication of gender violence. In fact, not only has this movement resulted in the exposure of public figures but, as far as Elizabeth Tippett is concerned (2018: 298), it has sparked the changing of laws concerning sexual harassment and discrimination in the workplace. Furthermore, the movement has also reignited second-wave debates like the ratification of the $E R A$ (Equal Rights Amendment) in the United States or the victimhood discourse, the idea that women are structurally victimized in society as a result of patriarchy (Tokaji 2018: n.p.).

Apart from being reminiscent of the second-wave collectivism, the Me Too movement seems to have contributed to the revitalization of the language of sisterhood itself. As I will discuss in the following section, the terms sister and feminist, which gained public acclaim during the 1960s, adopted negative connotations with the arrival of the third wave despite the continuity of feminist political activism (Siegel 2007: 13). It is worth mentioning that the use of the term third wave in this paper is selective, as in Siegel's case, and alludes exclusively to the white middle-class liberal ideology. While I am aware that the third wave is characterized by being more inclusive than the previous one, embracing different versions of feminism which may even contradict one another, I have chosen to focus on the one which, according to many scholars, is culturally predominant. This is the case for R. Claire Snyder (2008: 181), Siegel (2007: 16) and Ednie Kaeh Garrison (2007: 188), among others. Now, in the midst of the fourth wave and with the significant contribution of $\mathrm{Me}$ Too, the "feminist label" is once again being reclaimed in mainstream popular discourse (Rottenberg 2018a: n.p.). While celebrities and public figures from Taylor Swift to Ivanka 
Trump are describing themselves as feminists, companies like Dior have coopted prominent second-wave slogans like "Sisterhood is global" or "Sisterhood is powerful" to launch their new season line (Conlon 2019: n.p.). Nonetheless, it is here where we find a fundamental difference between the fourth and the second wave. As Catherine Rottenberg points out, the language of sisterhood has regained public recognition, but at the expense of being used as a tool of the neoliberal market to promote individual power through consumption, rather than actual political change (2018a: n.p.).

My contention that Fay Weldon's novel remains relevant in today's culture aligns itself with the notion put forward by Chamberlain (2017) and Rivers (2017) that the evolution of feminism is not a linear succession of waves continuously substituting each other. On the contrary, Chamberlain argues that the feminist movement has constituted a constant "back and forth" with regards to many issues, meaning that the waves do not actually annul each other, but rather overlap (2017: 138). Thus, while the fourth wave has witnessed the public return of the language of sisterhood and the sudden surge of a movement which is reminiscent of second-wave solidarity, feminism is still imbued in many of the attitudes of the third wave, such as the promotion of individual empowerment and agency rather than collective action (Rivers 2017: 24). According to Rivers, the fourth wave has inherited the complexity and fragmentation of the previous wave, and therefore cannot be reduced to one single narrative (24). However, as I mentioned before, there is one strand of feminism which still seems to dominate popular discourse in Western society, that which deals with the experience of mostly white middle-class women. This is not to deny the significant presence that intersectionality has in academic feminism, nor the influence of areas such as postcolonial or Black feminist theory. However, even scholars who examine the potential of a more inclusive and intersectional feminism recognize that, on a cultural and political level, there is still a hegemonic discourse (Rivers 2017; Garrison 2007; Snyder 2008).

In this paper I will explore two main topics, which are as relevant to the fourth wave as they were back in the 1960s, from the perspective of Fay Weldon's novel Female Friends (1974), one of the first significant works to depict female relations on a protagonist plane. The first topic is the issue of sisterhood and the other one is related to women's victimization and empowerment in society. Firstly, I will address the concept of sisterhood, exploring its use and relevance in Western society since the second wave until the present day. Secondly, I will explore the complexities of female bonding in Weldon's novel, arguing that the novel's realistic portrayal of female friendship challenges some of the premises that were underlying the idealization of this term during the second wave, particularly the notion of a unitary female identity and the victimhood discourse. Finally, my goal is to contend how the novel remains culturally relevant amidst the fourth wave through its endorsement of women's individual agency. My contention is that, while the novel does indeed advance the possibility of sisterhood, it presents it as a relation which can become more beneficial through women's self-critique and self-empowerment rather than shared victimization.

\section{THE RELEVANCE OF SISTERHOOD: THEN AND NOW}

Before I move on to explore how Weldon depicts the concept of sisterhood in her novel, it is vital that I discuss the significance of this term during the second wave (1960s) and how 
it has evolved until the present day. Furthermore, it is essential to point out that the term sisterhood already existed prior to the 1960s, and that its politicization actually took place during the women's suffrage, when the term was used to define the international gathering of women fighting for equal rights (Bolt 2005: 15). The particularities of this wave, while essential for a deep understanding of the feminist movement, are not directly relevant for the arguments that I present here, which is why I will not discuss them in this paper.

The adoption of sisterhood as a metonymy for the second wave began in the early $1960 \mathrm{~s}$ in the United States, where women activists took to creating consciousness-raising groups in order to advocate for women's civil rights and spread awareness on women's structural oppression (Thornham 2001: 30). According to Marilyn Yalom and Theresa Donovan-Brown (2015: 274), it was through those groups that the term sisterhood started to circulate as a way to define a new form of female friendship with a political undertone. Paullina Palmer agrees with this premise, claiming that the process of consciousness-raising was primarily focused on identifying the "common aspects of female experience", particularly the intrinsic condition of women as victims of male oppression (1989: 126). Even though, as Imelda Whelehan maintains, the feminist movement was actually propelled by inner dissidence and disagreement, the "rhetoric" of sisterhood rapidly gained public acclaim as an almost idyllic image of "a singular, shared vision of change" (2015: 114). United as 'sisters' by their biological condition and their shared experience as women, feminists advocated that the personal is political and that together they would be able to achieve equality. Among their political demands was the demand for free contraception and abortion, which would later be expanded to include the premise of freedom from male violence and coercion (116-117). It was actually during this movement that the term rape culture, which is a central part of today's feminist discourse, was established (Peters \& Besley 2019: 460).

The concept of sisterhood therefore entailed both a personal relation, as a female refuge from patriarchy, and a political alliance, as a union that was meant to propel women's liberation in society. The term itself symbolized equality among women, in contrast with other female relations like the mother-daughter bond. In fact, the latter was deemed almost as pernicious as heterosexual relationships, seeing that the mother was rendered an accomplice in women's self-negation and subjugation to men (Hirsch 1989: 133). Nevertheless, the fixation on women's common experience, which was initially what propelled the euphoric view of sisterhood, became, paradoxically, the object of critique in the later years of the movement. Apart from the fact that some of the political victories of the 1970s, such as Roe v. Wade, started to be undermined (Siegel 2007: 105), the feminist movement became fragmented as internal disagreements increased. Sue Thornham claims there was a constant tension between the liberal feminists, who wanted to focus specifically on women's economic equality, and the radical feminists, who were fixated on dismembering the system that was purposefully designed to oppress the female body as a whole (2001: 38). Meanwhile, Deborah Siegel suggests that the more women joined the movement, the more difficult it became to remain united, since there were diverse opinions on the type of approach the movement should take (2007: 50).

Finally, with the arrival of the 1980s and the establishment of Women's Studies programs, the main premises underlying the notion of sisterhood were critically analyzed and challenged (Palmer 1989: 126). Scholars focused on how the term had been used as a 
metaphor which had tried to contain all women under one identity - that of white, middleclass heterosexual women-, without successfully exploring the differences between them. For instance, Whelehan explains how the term had "perpetuated ethnocentric concepts" by correlating sexism and racism and how it had disregarded the experiences of minority groups such as black, lesbian or working-class women (2015: 124). Paradoxically, as society witnessed significant positive changes in terms of women's equality, the concept of sisterhood inevitably adopted negative connotations within mainstream popular discourse (Siegel 2007: 118). Here I must note that this was not the case for Black feminist discourses, where the notion of sisterhood remained present due to its strong ethnic-attachment, which can be traced back to pre-colonial times (McDonald 2007: 68). Meanwhile, among the new generations of middle-class women, the idea of collective political action started to lose attraction, and the call for sisterhood began to be equated to the celebration of victim feminism (Siegel 2007: 20), the notion that women lack individual agency as a result of their intrinsic victim status. The emphasis on women's victimhood was deemed by many young working women as an obstacle preventing them from competing with their male counterparts in the professional world.

The rejection of sisterhood as a discourse of victimhood and female homogeneity was consolidated in the 1990s, with the arrival of the third wave. Within this new wave, which was characterized by multiplicity and contradiction (Snyder 2008: 176), the term girl power started to resonate with younger audiences (179). Through girl power, the professional woman was encouraged to substitute sisterhood with competition and self-improvement (McRobbie 2009: 73). Thus, the discourse of victim feminism, still advocated by the second-wavers, gave way to the discourse of power feminism, a term coined by Naomi Wolf which advocates women's individual agency and self-empowerment (Siegel 2007: 116). The problem with this individualistic discourse, according to Siegel, is that it promotes the idea that women are "invincible" and that they therefore do not need collectivity to survive, leading to a new movement "lacking in empathy" (126).

Now, in the midst of the fourth wave, while sisterhood has returned to popular discourse, mainly through social media platforms, the individualistic discourse remains. I have already mentioned how the Me Too movement has promoted female solidarity by encouraging the exposure of sexual harassment, and how its sudden impact has contributed to the modification of certain workplace policies. However, whether the notion of sisterhood will continue to work as a collective political stimulus or will simply become a popular catchword in the new digital era remains to be seen.

\section{WELDON'S FEMALE FRIENDS AND THE SISTERHOOD METAPHOR}

Having established the importance of the sisterhood metaphor during the second-wave feminist movement, I will now proceed to explain how Fay Weldon's novel Female Friends (1974) challenges two of its main premises, in line with the thinking of the third and fourth wave. My contention is that, through the portrayal of an imperfect female friendship, the novel rejects the notion of a unified female identity and shows how shared victimization may not be the best way to sustain sisterhood, becoming instead an obstacle in women's personal and political development. 
Weldon's novel focuses on the lives and experiences of three middle-aged women living in 1970s London: Chloe, Marjorie and Grace. The story is mainly told from Chloe's point of view, who alternates scenes from the present with flashbacks of these characters' past experiences. Through her narration, we learn that the friends meet each other as children in a town named Ulden, where they are initially drawn together by solace and the identification of each other's suffering. Their childhood friendship ends up transforming into a life-long bond which, however imperfect, is a constant in their lives. I now plan to examine this bond according to 3 paradigms, through which we will be able to observe the novel's depiction of sisterhood: difference, victimhood and solidarity.

First let us focus on the paradigm of difference. Even though they are all white, middleclass heterosexual women, the protagonists have different individual goals and moralities. Chloe, on the one hand, is a Christian devoted housewife with no apparent ambitions other than her determination to be an exemplary wife and mother. Then there is Grace, a seemingly self-involved woman who enjoys looking for young men who will provide for her and make her feel young and attractive. Finally, Marjorie embodies the role of the 1960s' feminist, since she is a single independent woman working for the prestigious BBC corporation. After her long-term boyfriend Ben dies unexpectedly, she finds it difficult to establish meaningful heterosexual relationships.

The dissimilarity between these protagonists is not intrinsically what creates the tensions in their friendship, but rather their initial disregard for the other women's life choices. This echoes the problematic of the second wave. As Janice Raymond maintains, sisterhood was constructed under the illusion that women's common experience was enough to sustain female bonding, which consequently led to the inability to recognize individual differences (1986: 197). In the novel, Chloe's refusal to abandon her husband, who is cheating on her with their French maid, Françoise, is met with the disapproving eye of her friends, even when they are fully aware that Chloe has nowhere to go and would never leave her children behind. As a consequence, she is referred to as a martyr, given that she seems to welcome everything that comes her way with an enduring spirit, just like her mother taught her: "Understand, and forgive" (Weldon 2014: 1). This is what Chloe constantly repeats throughout the novel, which showcases her predisposition for self-sacrifice. Like her mother, she has been deprived of selfhood through patriarchal education, which leads her to claim that women live by "necessity" (83). Chloe's martyrdom is a constant source of tension in the characters' friendship, as exemplified through Marjorie's confession to her: "I don't trust your judgement any more" (96). As Marilyn Friedman maintains, when there are sharp dissimilarities between friends it can be difficult to understand and validate the other person's moral values, thereby creating distrust in the relationship (1995: 205).

However, it is not only Chloe's actions that are disapproved by the group. Even though she has an overall pessimistic outlook of life, Chloe strongly believes that motherhood and marriage are self-fulfilling goals, and thus the idea of living as a single woman seems even worse for her than having an unhappy married life: "Poor little Marjorie, obliged by fate to live like a man [...] Childless, deprived of those pilferings into past and future with which the rest of us, more fertile, more in the steady stream of generation, enrich our lives" (Weldon 2014: 9). Grace also shows contempt for Marjorie's independent life, claiming that the only way a woman can be successful in the business world is by providing sexual 
favors to her boss. Paradoxically, Marjorie's acknowledged superiority of working women over housewives clashes with her habit of washing her ex-boyfriend's clothes, an activity which makes her feel 'womanly'.

This double standard can also be applied to Grace, whose carefree lifestyle is mocked on more than one occasion by her friends. While Grace looks at Marjorie's decision to wash Patrick's clothes as a habit of "deferring to the male" (98), she is economically dependent on her boyfriend Sebastian, who is fifteen years younger than her. Grace's apparently superfluous life, which mainly consists of remaining sexually attractive for as long as possible, is seen as a clear sign of immaturity by both Chloe and Marjorie. Chloe claims to feel "morally superior" to her friend (14), whereas Marjorie's disapproval appears to stem from jealousy at times: "I don't really mind Grace being happy. It's just that she always has such a good time. I know it's at other people's expense, trample, trample on all and sundry. I just wish I had the courage" (54). Unlike Chloe and Marjorie, Grace seems to worry about no one but herself, even at the expense of her children.

Chloe's and Grace's diverging attitudes towards motherhood also contribute to creating tensions in their friendship. Chloe, on the one hand, feels that her role as mother of five children - only two of them being biologically hers -, demands the annihilation of her individual female selfhood. As a result, it is impossible for her to be "maternal" and "erotic" at the same time (123). For her, motherhood is a sacrifice that is required to achieve selffulfillment, an essentialist view which, according to Marianne Hirsch (1989: 136), is highly problematic for second-wave feminists, since it inevitably ties women to the role of nurturer.

Grace, on the other hand, seems to be completely disconnected from her maternal self. Her propensity for abortions reflects a common literary trope of the second wave, one which Whelehan refers to as "the prison-house of motherhood" (2015: 115). In the novel we see this correlation between motherhood and oppression through Grace: "She loves anaesthetics and feels only relief when the baby's gone and she's no longer nauseous" (Weldon 2014: 121). Furthermore, after Grace loses custody of her son Stanhope, she is clearly disinterested in bonding with him, despite Chloe's constant attempts to reunite them. This is an enduring source of tension between these characters, especially because it was Chloe who convinced Grace to have the baby, which Grace audibly regrets: "I should have had an abortion. I should never have listened to you" (101). Chloe's fierce determination in preventing Grace's abortion stems from her own conceiving problems, as well as her inability to understand her friend's dismissal of motherhood. The juxtaposition between these two characters, the martyr and the narcissist, and their opposite stance on motherhood, helps Weldon challenge the notion of a homogeneous female identity and experience.

The other paradigm which shapes the protagonists' friendship is victimhood. In an attempt to challenge the second-wave premise that shared victimization is enough for the foundation of sisterhood, the novel proposes that this singular focus may actually become detrimental for the relationship over time. As Raymond concurs: "Constant and one-dimensional focus on the sharing of pain can drive women away from strong female friendships by obscuring the historical reality that women have been and can be for women in other than sisterly suffering ways" (1986: 182). This idea is also present in Weldon's novel. The protagonists' inability to move past their victim status, which is what initially helped forge their friendship, is also what is keeping them from growing and developing a 
politically-significant bond: "Marjorie, Grace and me. How do we recover from the spasms of terror and resentment which assail us, in our marriages and in our lives?" (Weldon 2014: 140). Weldon establishes the mother-daughter bond as the root of the protagonists' victimization, a decision which clearly echoes the second-wave rejection of the mother as an accomplice to patriarchy.

I have already stated how Gwyneth teaches Chloe to willingly engage in self-negation, but she is not the only mother that is depicted as being responsible for her daughter's adult victimhood. Adela Matei contends that, in Marjorie's case, it is her mother's neglect and physical abandonment as a child that leads to Marjorie's "identity crisis" (2014: 42), which finally consolidates in the form of low self-esteem and resentment towards life: "I am one of nature's dead-ends. I am a walking Black Hole" (Weldon 2014: 51). This notion of emptiness resembles Chloe's feeling of martyrdom: "Chloe knows she never can be filled. Some wounds have gone too deep, protective membranes have been torn and can't be mended" (96). Thus, no matter their opposite personal and professional lives, they both feel equally incomplete.

In the same way that Marjorie's job is not enough to compensate for her emotional neglect as a child, Grace's attractiveness and her relatively untroubled life turns out to be insufficient in the absence of motherly nurturance. Her mother Esther fails to acknowledge her daughter on account of Grace's unwillingness to copy her compliant behavior in the home. As a result, Esther transfers her affection to Marjorie, who does respond positively to her teachings in light of the absence of Marjorie's own birth mother. Meanwhile, Chloe also spends most of her childhood without her mother, not because Gwyneth has abandoned her, but because her exploitative job prevents her from spending time with her daughter. This situation, according to Agate Krouse (1978: 8), leaves Esther to fulfill the role of mother for all three girls, which also contributes to their feeling as sisters: "we three sisters, walking wounded" (Weldon 2014: 304).

Finally, we reach the paradigm of solidarity, and I argue that the women's dysfunctional relation with their respective mothers is juxtaposed with their friendship in an attempt to show the tolerant side of the latter. Following Hirsch's discourse on the mother-daughter bond, the sisterhood ideal of the second wave offers women an alternative to the mother's nurturance, allowing them the freedom they need from traditional gender roles, which is something that the patriarchal mother cannot offer (1989: 136). The novel reflects this clearly. Despite the constant tensions in their friendship, and the moral superiority that each woman seems to evince from time to time, the protagonists do not end their friendship on the basis of the other women's actions, however socially deviant. This clearly contrasts Esther's decision to ostracize her daughter after Grace refuses to comply to her teachings, or Gwyneth's disinterest in Chloe's life after she marries and gets pregnant without her permission. Therefore, as Krouse contends, the failure to act according to one's own expectations, both in terms of "behavior" and lifestyle, does not constitute in the novel a viable reason for the breaking of sisterhood, only of motherhood (1978: 8). Towards the end of the novel, the act of acceptance that is practiced by the protagonists as part of their commitment to one another evolves in the direction of a more active feminist solidarity, making it clear that Weldon is, after all, hopeful about sisterhood. 
However, before this can happen the protagonists must reevaluate their decisions and admit to their dissatisfaction. At one point or another, they all agree that they feel stuck, unable to move forward, as can be viewed by Marjorie and Chloe's discussion (Weldon 2014: 67):

'Oh Chloe,' says Marjorie. 'Nothing ever changes.'

'Yes it does,' says Chloe. 'It must.'

But it doesn't really. This is what it's like now and then it was much the same. You ask for bread, and get given stones.

Not long after, when Marjorie is at the hospital visiting her mother Helen, she feels surprised by the appearance of Chloe and Grace, who have gone there to support her. It is at this moment when the characters speak for the first time about the nature of their relationship: "We were none of us all that much help to each other" (283). With this declaration, Marjorie denounces the lack of active solidarity in their relationship, a situation which will change by the end of the novel, as we will see in the following section.

To sum up, it has been my intention to demonstrate how the novel challenges, in line with the thinking of the third and fourth wave, two main premises underlying the idealization of sisterhood: the idea that behind sisterhood lies a homogenous female identity and the notion that shared victimhood is the propelling force for feminist political change. Although the women are there for each other emotionally when times are hard and they ultimately accept each other, unlike their own mothers, they sometimes fail to explicitly validate the other women's choices, believing them to be morally inferior to their own. Furthermore, they delve too much in their own victimization and pain, which prevents them from visualizing their individual and collective potential. In the next section, I will attempt to demonstrate how the novel advances the importance of individual agency as a necessary step towards self-empowerment and sisterhood.

\section{THE ENDORSEMENT OF INDIVIDUAL AGENCY IN THE CONSTRUCTION OF SISTERHOOD}

My aim in this section is to examine how, despite Weldon's questioning of the main premises embedded in the second-wave's euphoric view of sisterhood, the novel endorses the possibility of sisterhood by combining it with the individualistic discourse of the third and fourth wave, thereby making the novel relevant in today's culture. On the one hand, I argue that Weldon rejects the victimhood discourse by depicting the protagonists as women who are able to take control of their lives. On the other hand, I contend how each women's individual agency is key in their own empowerment and the transformation of their friendship into a politically meaningful bond.

Firstly, I maintain that the novel questions the women's victim status by presenting them as the perpetrators rather than simply the victims of violence. This is particularly evident in the case of Grace, who is presented as someone who has the ability to be as cruel as the men in Weldon's novel. For instance, she once tells Chloe that she deserves being cheated on for her impassive attitude, which deeply affects the latter. Furthermore, the protagonist claims she enjoys doing harm, which is evident when it comes to her ex-husband's new 
wife Geraldine, whom she regularly harasses and slanders by "heavy breathing down her telephone night after night" or "painting 'mass murderer' in gloss paint on her mini" (Weldon 2014: 207). Although Chloe claims that, deep down, Grace is sorry for this woman, her actions are no less deplorable because of it. As Kelly Vallen maintains, viewing women's cruelty as a result of patriarchal education obscures the reality that women can and should rethink the way they treat each other (2010: 17).

It is clear that Weldon does not intend to depict any of the protagonists as innocent, as exemplified through the women's acknowledgement of their role in Midge's death. Midge was the wife of Patrick, who abandoned her soon after their marriage, refusing to provide for her and their baby while having affairs with other women, like Grace. Despite the fact that all the protagonists are well aware of her situation, they find some sort of excuse to avoid doing anything about it. In the case of Grace, she refuses to feel guilty, placing all the responsibility on Midge, whom she believes should divorce Patrick and strive for alimony, as she tried to do with Christie. Marjorie, on the other hand, fails to help Midge because she is always busy at work, although, paradoxically, she takes the time to convince Midge to be a part of her documentary about "women with wasted lives", a title which clearly reflects her lack of empathy towards her (Weldon 2014: 291). Finally, Chloe is the only one who actually admires Midge, given their common devotion to a hopeless cause: "Midge seems in some vague way her, Chloe's, moral superior" (290). This, however, also prevents Chloe from helping Midge, as she attempts to become more like her. Finding herself utterly lonely and desperate, without any friends or family to support her, Midge finally commits suicide.

It is not coincidental that Weldon waits until the end of the novel to explain the role that the protagonists had in Midge's victimization, since this is also the point where Chloe's transition from victim to self-empowered subject finally takes place. The reader is warned from the beginning of Chloe's intention: "Understand and forgive, my mother said, and the effort has quite exhausted me. I could do with some anger to energize me, and bring me back to life again" (1). Weldon then assures us that this change in the protagonist's life will occur "through some alteration of attitude" (2). Chloe's change of 'attitude' goes from acknowledging her own mistakes, like her failed attempt to help Midge, to dismissing Gwyneth's teachings of the submissive woman, an action which furthers, as Mara Reisman concurs (2011: 648), the notion that women are able to empower themselves. Although Grace and Marjorie keep trying to compel her to leave Oliver, it is not until Chloe accepts her right to happiness and abandons her position as martyr that she is able to benefit from the support of her friends. Her transition from victim to subject is made explicit in the way the narrator closes the novel: "I no longer wait to die" (Weldon 2014: 306).

While Chloe's individual agency is key to her transition from martyr to subject, Grace's inner strength and determination contributes to her transformation from narcissist to caring mother. Her sudden change in attitude can be explained as an attempt to distance herself from the fate of Helen, who used to be her role model and whom by the end of the novel she sees as someone on the verge of dying alone. Not wanting to end up like her, Grace decides to start caring more about other people, starting with her son Stanhope. Furthermore, she is the first one to evince the possibility of sisterhood by equating friendship with solidarity. After hearing that Helen is in the hospital, Grace insists to Chloe that they must visit Marjorie, 
even if she has not explicitly asked either of them to go and support her: "If you're going to be someone's friend, you have to intrude your friendship sometimes" (266).

The possibility of sisterhood is also put forward by Marjorie. As we saw in the previous section, she is the character that denounces the protagonists' friendship for not being solidary enough. She then continues to explain her own vision of what their friendship should be like, a vision which, for Krouse (1978: 9), embodies Weldon's own mind too:

We should interfere more in each other's lives, and not just pick up the pieces. I should go and shoot Oliver, and you should commit Grace to an insane asylum, you should have got me to a marriage bureau a long time ago. See how it all ends-(Weldon 2014: 283-284).

With this reflection, which is certainly sarcastic in many ways, Marjorie advocates for a bond that works on both a personal and a political level. On the one hand, she is calling for a relation that provides emotional comfort beyond real hardship, which coincides with the discourse of power feminism. As Kelly Valen claims, women should bring out their "sisterly spirit" not only when the other women are going through adversity, but also when they are experiencing a joyful period in their lives (2010: 22). Weldon's novel advances a view of sisterhood that, on a personal level, is not there to "pick up the pieces", but rather to build each other up and promote women's strengths. On the other hand, Marjorie proposes that the women make a more active effort in helping each other achieve happiness. She even takes the first step in this direction by offering Chloe her mother's house so that she can abandon Oliver and have a place to live with her children. With this solidary act, Marjorie contributes to both her friend's and her own empowerment. By letting go of her childhood home, she is able to move on from a constant reminder of her mother's neglect while also helping her friend start afresh in life.

As we can observe, the vision of sisterhood that the novel endorses is necessarily dependent on the premise that women are capable of taking control of their own lives. In line with the individualistic discourse, the protagonists only manage to strive towards self-assertion and happiness once they reevaluate and modify their attitude towards life and their behavior towards each other. Weldon seems to concur with Valen's premise that blaming men or society for women's unhappiness obscures the possibility of change as well as the dangers of female bullying, which Valen believes to be normalized in contemporary culture (2010: 17).

To conclude this article, Weldon's novel remains relevant in today's fourth feminist wave in the way it combines two discourses which have conventionally been considered as contradictory: the discourse of sisterhood and the discourse of women's individual empowerment. On the one hand, she challenges some of the premises that were contained in the idyllic vision of sisterhood of the 1960s. By portraying the individual lives and issues of a group of ordinary women, Weldon demonstrates the illusion of a unified female identity and the dangers of viewing women on the basis of their hardships, rather than their strengths and potential for change. This does not mean, however, that Weldon dismisses the possibility of sisterhood. On the contrary, the novel encourages, in line with the second wave, the practice of solidarity. Although Chloe's transition into an empowered subject is rooted in her individual agency, it is thanks to Marjorie that she is physically able to leave her husband. Without her female network, this would have been a lot more difficult, 
if we take into account Chloe's weak financial situation. So, in this sense, the novel also challenges the notion of girl power characteristic of the third and fourth wave, which poses that a woman's self-determination lies entirely on her hands. In the novel, Midge's fate can be interpreted as a parallel to Chloe's, since Midge's suicide ultimately derives from a lack of external support. However, it is worth noting that Midge's voluntary submission to her husband, even after she realizes his indifference towards her, is also a contributing factor leading to this event.

\section{CONCLUSIONS}

Thus, the author does not align herself completely with either of the feminist waves, demonstrating her artistic independence as well as her contribution to the dismantling of the wave narrative. The novel endorses, through Chloe's character, a vision of sisterhood which is necessarily dependent on the notion of women's individual agency. The protagonist must first engage in self-criticism and adopt a more assertive attitude before she can benefit from sisterhood and help other women who are more helpless than her, like Midge. Finally, apart from combining feminist discourses of different eras, Weldon tackles topics which are as relevant today as they were back in the 1960s, such as the issue of violence against women or the importance of feminist solidarity, as we have seen with the effects of Me Too.

\section{REFERENCES}

ArAVIND, I. 2018. “\#MeToo movement: Women call out their past tormentors on social media." The Economic Times. Mumbai. 25 February. 2020. https:/economictimes. indiatimes.com/news/politics-and-nation/metoo-movement-women-call-out-their-pasttormentors-on-social-media/articleshow/66198396.cms

Bolt, C. 2005. Sisterhood Questioned? Race, Class and Internationalism in the American and British Women's Movements, c. 1880s-1970s. London: Routledge.

Chamberlain, P. 2017. The Feminist Fourth Wave: Affective Temporality. London: Palgrave Macmillan.

Cochrane, K. 2013. All the Rebel Women: The Rise of the Fourth Wave Feminist. London: Guardian Books.

Conlon, S. 2019. "Christian Dior launches latest 'sisterhood' slogans." The Guardian. London. 27 February. 2020. https:/www.theguardian.com/fashion/2019/feb/26/ christian-dior-launches-latest-feminist-slogans

Friedman, M. 1993. What are friends for? Feminist Perspectives on Personal Relationships and Moral Theory. Ithaca: Cornell UP.

GARrison, E. K. "Contests for the Meaning of Third Wave Feminism: Feminism and Popular Consciousness." Third Wave Feminism: A Critical Exploration (2 $2^{\text {nd }}$ edition). Eds. S. Gillis, G. Howie \& R. Munford. Hampshire and New York: Palgrave Macmillan. 185-197. 
Harman, H. 2018. "Women have changed the mood. Now we need to change policy." The Guardian. London. 21 February. 2020. https:/www.theguardian.com/ commentisfree/2018/feb/21/women-have-changed-the-mood-now-we-need-to-changepolicy

Hirsch, M. 1989. The Mother/Daughter Plot: Narrative, Psychoanalysis, Feminism. Bloomington and Indianapolis: Indiana UP.

Krouse, A. 1978. "Feminism and Art in Fay Weldon's Novels”. Critique 20, II: 5-20.

Matei, A. 2014. “Deconstructing Female Friends”. Cultural Intertexts I: 39-44.

McDonald, K. B. 2007. Embracing Sisterhood: Class, Identity and Contemporary Black Women. Lanham: Rowman \& Littlefield Publishers.

Mcrobire, A. 2009. The Aftermath of Feminism: Gender, Culture and Social Change. London and Thousand Oaks: SAGE.

Palakurthi, A. 2015. "SlutWalk marches on against sexual assault, victim blaming." The Daily Campus. Connecticut. 21 February. 2020. http://dailycampus.com/ stories/2015/9/21/slutwalk-marches-on-against-sexual-assault-victim-blaming

PAlmer, P. 1989. "Sisterhood, relations between women, and women's community." Contemporary Woman's Fiction: Narrative practice and Feminist Theory. New York: Harvester Wheatsheaf. 125-158.

Peters, M. \& Besley, T. 2019. “Weinstein, Sexual Predation, and 'Rape Culture': Public Pedagogies and Hashtag Internet Activism”. Educational Philosophy and Theory 51, V: 458-464. DOI: 10.1080/00131857.2018.1427850

Pflum, M. 2018. “A year ago, Alyssa Milano started a conversation about \#MeToo. These women replied.” NBC News. New York. 24 February. 2020. https://www.nbcnews. com/news/us-news/year-ago-alyssa-milano-started-conversation-about-metoo-thesewomen-n920246

Raymond, J. 1986. A Passion for Friends: Toward a Philosophy of Female Affection. Boston: Beacon Press.

ReISMan, M. 2011. “The shifting Moral Ground in Fay Weldon's Fiction”. Women's Studies: An interdisciplinary journal 40, V: 645-671. DOI: 10.1080/00497878.2011.581551

Rivers, N. 2017. Postfeminism(s) and the Arrival of the Fourth Wave: Turning Tides. Cheltenham: Palgrave Macmillan.

RottenberG, C. 2018a. "Feminists must reject neoliberalism if we want to sustain the MeToo movement." The Independent. London. 25 February. 2020. https://www. independent.co.uk/voices/neoliberalism-colonised-feminism-metoo-sheryl-sandberghollywood-a8367326.html

SIEGEL, D. 2007. Sisterhood Interrupted: From Radical Women to Grrls Gone Wild. New York and Hampshire: Palgrave Macmillan. 
SNYDER, R. C. 2008. "What Is Third-Wave Feminism? A New Directions Essay”. Signs 34, I: $175-196$. DOI: $10.1086 / 588436$

Thornham, S. 2001. "Second Wave Feminism." The Routledge Companion to Feminism and Postfeminism. Ed. S. Gamble. London and New York: Routledge. 29-42.

Tippett, E. 2018. "The Legal Implications of the MeToo Movement”. Minnesota Law Review 103: 229-302.

ToKAJI, A. 2018. "Why \#IDidThat is better than \#MeToo." The Sydney Morning Herald. Sydney. 26 February. 2020. https://www.smh.com.au/national/why-ididthat-is-betterthan-metoo-20180227-p4z1zo.html

VAlen, K. 2010. The Twisted Sisterhood: Unraveling the Dark Legacy of Female Friendships. New York: Ballantine Books.

Weldon, F. 2014. Female Friends. London: Head of Zeus Ltd. (Original work published 1974).

Whelehan, I. 2015. “The Monstrous Regiment: Literature and the Women's Liberation Movement." The History of British Women's Writing, 1970-Present. Eds. M. Eagleton \& E. Parker. Hampshire: Palgrave Macmillan. 114-129.

Yalom, M. \& Donovan-Brown, T. 2015. The Social Sex: A History of Female Friendship. New York: HarperCollins. 